DOI

\title{
ПОРІВНЯЛЬНА ХАРАКТЕРИСТИКА НАВЧАЛЬНИХ ПЛАНІВ БЛОКУ БАЗОВИХ ХІМІЧНИХ ДИСЦИПЛІН ПІДГОТОВКИ ФАХІВЦІВ ЗА СПЕЦІАЛЬНОСТЯМИ “ФАРМАЦІЯ” ТА “ЛІКУВАЛЬНА СПРАВА” У МЕДИЧНИХ ВНЗ КРАЇН-АСОЦІЙОВАНИХ ПАРТНЕРІВ ЕРАЗМУС
}

\author{
Г. І. Фальфушинська, Л. М. Іванець, Г. Я. Загричук
}

ДВНЗ “Тернопільський держсавний медичний університет імені I. Я. Горбачевського МОЗ України”

\section{COMPARATIVE CHARACTERISTICS OF GROUNDED CHEMICAL DISCIPLINES SYLLABUS FOR "PHARMACY” AND “MEDICINE” PROFESSION OBTAINING IN MEDICAL UNIVERSITIES OF THE COUNTRY - ERASMUS ASSOCIATED MEMBER}

\author{
H. I. Falfushynska, L. M. Ivanets, H. Ya. Zahrychuk \\ SHEI “Ternopil State Medical University by I. Ya. Horbachevsky of MPH of Ukraine”

\begin{abstract}
У статті розглянуто порівняльний аналіз структури навчальних програм та кількості кредитів блоку базових хімічних дисциплін підготовки фахівців за спеціальностями “Фармація” (неорганічна хімія, органічна хімія, фізична та колоїдна хімія) та “Лікувальна справа” (медична хімія) у ВНЗ України та країн Європи, які є асоційованими партнерами програми ЕРАЗМУС+.
\end{abstract}

In the article the comparative analysis of curriculum of study programs and number of credits for basic chemical disciplines which served for training of specialties "Pharmacy" (inorganic chemistry, organic chemistry, physical and colloidal chemistry) and "Medicine" (medical chemistry) in Ukrainian and European universities, which are associated members of ERASMUS+ program have performed.

Вступ. Європейська кредитно-трансферна система (ECTS) - студентоцентрована система, розроблена для уніфікації оцінювання рівня опанування навчальних планів студентів, що здобувають освіту в різних вищих навчальних закладах (ВН3) країн Європи, та їх академічного визнання [1]. Система ECTS базується на принципах взаємної довіри учасників і передбачає виконання правил щодо всіх її частин: ECTS-кредитів, ECTS-оцінювання та Угоди про навчання і перезарахування кредитів. Головна мета системи ECTS полягає в імплементації різними навчальними закладами уніфікованої шкали кількісних показників, за якими можна співвідносити програми навчання, i, таким чином, наближувати національні системи вищої освіти Європи [1]. Позаяк новий Закон України "Про вищу освіту” декларує компетентнісний підхід в побудові освітніх та навчальних програм з використанням методології ECTS та/або TUNING (гармонізація освітніх структур у Європі), метою нашої роботи було проаналізувати взаємоузгодження навчаль-

(ㄷ.Г.І.Фальфушинська, Л. М. Іванець, Г. Я. Загричук них програм та кількості кредитів блоку базових хімічних дисциплін підготовки фахівців за спеціальностями “Фармація” (неорганічна хімія, органічна хімія, фізична та колоїдна хімія) і “Лікувальна справа” (медична хімія).

Основна частина. Трансферна система ECTS, яка вперше була запропонована у 1989 р. у рамках освітньої програми ЕРАЗМУС, в наш час визнана основоположною в Європейському освітньому просторі, поширена у 30 країнах та впроваджена у діяльність більш ніж 1000 вищих навчальних закладів. Імплементація ECTS сприяє прозорості та академічному визнанню як формального, так і неформального навчання у різних вузах Європи, а відтак забезпеченню академічної мобільності студентів між партнерськими навчальними закладами. Останнє $є$ необхідною умовою для особистісного зростання студента, а також обов' язковим елементом освітнього процесу.

Починаючи з 2014 р., перед студентами та науковопедагогічними працівниками України відкрилися нові можливості: Європейська комісія затвердила довгострокову програму ЕРАЗМУС+, яка надає 
доступ учасникам проекту до програм академічної мобільності (студенти), ступеневої мобільності (студенти та викладачі), а також програм розвитку потенціалу ВН3 [1]. Однак, незважаючи на активне залучення України в програму ЕРАЗМУС+ та запровадження ЕСТS в Україні (з 2003 р.), існують певні труднощі з навчальним та науковим “туризмом” українських студентів-медиків та фармацевтів. Зокрема, це відсутність сертифікації та реального запровадження Національної рамки кваліфікацій, варіабельність навчальних планів та формалізм у переносі оцінок у навчальних закладах різного рівня.
Вартість кредиту в Україні, згідно з новою редакцією Закону “Про вищу освіту”, становить 30 год та є співмірною з такою ж у більшості країн Європи (25-30 год), за винятком Великобританії (16 год), Шотландії (10 год) та Латвії і Литви (40 год) [2-7].

В таблиці наведені дані по кількостях кредитів, які відводяться для хімічних дисциплін у ДВНЗ “Тернопільський державний медичний університет імені І. Я. Горбачевського МОЗ України” (ТДМУ) та в ряді європейських університетів [2-7].

Порівняння вимог навчальних планів з блоку базових хімічних дисциплін підготовки фахівців за спеціальністю “Фармація” та “Лікувальна справа”

Таблиця. Кількість кредитів блоку базових хімічних дисциплін підготовки фахівців за спеціальностями “Фармація” та “Лікувальна справа”

\begin{tabular}{|c|c|c|c|c|}
\hline \multirow{3}{*}{ BH3 } & \multicolumn{4}{|c|}{ Напрям підготовки } \\
\hline & \multicolumn{3}{|c|}{ фармація } & \multirow{2}{*}{$\begin{array}{c}\text { лікувальна } \\
\text { справа } \\
\text { медична } \\
\text { хімія }\end{array}$} \\
\hline & $\begin{array}{l}\text { неорганічна } \\
\text { хімія }\end{array}$ & $\begin{array}{l}\text { органічна } \\
\text { хімія }\end{array}$ & $\begin{array}{c}\text { фізична та колоїд- } \\
\text { на хімія }\end{array}$ & \\
\hline $\begin{array}{l}\text { Тернопільський державний медич- } \\
\text { ний університет }\end{array}$ & 8,5 & 9,0 & $\begin{array}{l}\text { 3,0 (фізична хімія)+ } \\
2,5 \text { (колоїдна хімія) }\end{array}$ & 6,0 \\
\hline $\begin{array}{l}\text { Віденський медичний університет } \\
\text { (Австрія) }\end{array}$ & NSP & NSP & NSP & 4,0 \\
\hline $\begin{array}{l}\text { Софійський медичний університет } \\
\text { (Болгарія) }\end{array}$ & 11,5 & 17,0 & 10,0 & 5,8 \\
\hline $\begin{array}{l}\text { Медичний університет Плівена } \\
\text { (Болгарія) }\end{array}$ & NSP & NSP & NSP & 6,0 \\
\hline Університет Дебрецена (Угорщина) & $8,0^{*}$ & 8,0 & 5,0 & 5,0 \\
\hline $\begin{array}{l}\text { Познанський університет медичних } \\
\text { наук у Польщі }\end{array}$ & 14,0 & 15,0 & 6,0 & 7,0 \\
\hline $\begin{array}{l}\text { Гданський медичний університет } \\
\text { (Польща) }\end{array}$ & 14,0 & 15,0 & 6,0 & 7,0 \\
\hline Пізанський університет (Італія) & 12,0 & 15,0 & $9,0 * * *$ & $6,0^{* *}$ \\
\hline Університет Саламанка (Іспанія) & 8,0 & 12,0 & $10,0 * * *$ & NSM \\
\hline Університет Бонна (Німеччина) & NSP & NSP & NSP & 7,0 \\
\hline Університет Нікозіа (Кіпр) & NSP & NSP & NSP & 12,0 \\
\hline $\begin{array}{l}\text { Університет Коменіуса в Братиславі } \\
\text { (Словаччина) }\end{array}$ & 8,0 & 12,0 & 7,0 & NSM \\
\hline $\begin{array}{l}\text { Університет Шафарика в Кошице } \\
\text { (Словаччина) }\end{array}$ & NSP & NSP & NSP & 8,0 \\
\hline Ризький університет Страдінга (Латвії) & NSP & NSP & $* * * *$ & 7,0 \\
\hline Сербія, Університет у Новому Саду & \begin{tabular}{|l} 
7,0 (загальна \\
хімія) + 5,0 (не- \\
органічна хімія) \\
\end{tabular} & \begin{tabular}{|l|}
7,0 (органічна \\
хімія I) + 6,0 \\
(органічна хімія II)
\end{tabular} & $\begin{array}{l}\text { 7,0 (фізична хімія) + } \\
\text { 3,0 (колоїдна хімія - } \\
\text { елективний курс) }\end{array}$ & \\
\hline Словенія, Люблянський університет & 8,0 & 9,0 & $\begin{array}{l}\text { 6,0 (фізична хімія) }+ \\
\text { 5,0 (колоїдна хімія) }\end{array}$ & \\
\hline
\end{tabular}

Примітка. * - у тому числі основи якісного аналізу; ** _ “Хімія і пропедевтична біохімія”, *** - інтегрований курс “Прикладна фізика та фізична хімія” - дисципліна не викладається; NSP - спеціальність “Фармація” відсутня та/або не включена в програму академічної мобільності ЕРАЗМУС; NSM - спеціальність “Лікарська справа” відсутня, **** - дисципліна відсутня у національних навчальних програмах. 
у ТДМУ та в 15 провідних медичних університетах Європи, включених до програми ЕРАЗМУС, свідчить, що максимальний відсоток збігів за кількістю кредитів характерний для дисципліни “Медична хімія” (“Лікувальна справа”, 72,7%), а мінімальний - для дисципліни “Органічна хімія” (“Фармація”, 22,2%). “Неорганічна хімія” і “Фізична та колоїдна хімія” займають проміжне положення (“Фармація”, близько 50 \%). Найбільш подібними за кількістю кредитів з усіх хімічних дисциплін до ТДМУ є навчальні програми Університету Дебрецена (Угорщина). Однією з причин відмінності кількості кредитів за блоком базових хімічних дисциплін $є$ порівняно вища частка блоку суспільногуманітарних дисциплін у ТДМУ (12 кредитів, згідно з рекомендаціями МОН) порівняно з європейськими ВН3 (6-8 кредитів) [2-7].

Незважаючи на варіабельність кредитів ECTS за хімічними дисциплінами в аналізованих медичних ВНЗ, зміст відповідних навчальних програм подібний. За консервативністю змісту програм дисципліни можна розташувати в ряді “Неорганічна хімія" > “Медична хімія" > “Органічна хімія” > “Фізична та колоїдна хімія” [2-7]. Зокрема, програма курсу “Неорганічна хімія” повною мірою охоплює основні теоретичні положення загальної хімії та хімії елементів, дозволяє студенту засвоїти практичні навички якісного аналізу основних хімічних елементів $s$-, $p$ - та $d$-блоків, які лежать в основі методів стандартизації та контролю якості лікарських препаратів, визначення фізичних показників чистоти реагентів та/або субстанцій лікарських препаратів (густина, показник заломлення, температура кипіння чи плавлення), проведення їх очистки методами дистиляції, фільтрації, перекристалізації, сублімації тощо.

Під час вивчення медичної хімії як у ТДМУ, так і в більшості ВНЗ Європи [2-7] основна увага зосереджена на засвоєнні базових знань, вмінь та навичок за темами “Будова атома”, “Розчини. Колігативні властивості розчинів”, “Буферні системи”, “Термодинаміка”, “Кінетика хімічних реакцій”, а також “Фізико-хімічні методи аналізу” (в ТДМУ ця тема не виноситься окремою темою, а інтегрована у вищезазначені).

Органічна хімія належить до природничонаукового блоку дисциплін при підготовці фахівців спеціальності “Фармація”. Зміст навчальних програм при цьому і в Україні, і ВНЗ європейських країн практично ідентичний [2-7] (“Теорія будови органічних сполук та їх реакційної здатності”,
“Методи встановлення будови органічних сполук”, “Вуглеводні”, “Галоген, оксисен, нітроген похідні вуглеводнів”, “Гетерофункціональні сполуки”, “Гетероциклічні сполуки”, “Природні сполуки” тощо), хоча можуть відрізнятися підходи до вивчення класів органічних сполук: або через вивчення хімічних властивостей функціональних груп, або через вивчення хімічних властивостей класів органічних сполук через типи органічних реакцій. В останні роки значна увага приділяється вивченню сучасних інструментальних фізикохімічних методів аналізу органічних сполук. У країнах Європи при вивченні хімічних властивостей органічних сполук більша увага приділяється квантово-хімічному поясненню механізмів реакцій та їх реакційної здатності тощо.

Зміст навчальних програм 3 фізичної хімії в різних ВНЗ практично збігається [2-7] і включає однакові розділи: хімічна термодинаміка, термодинаміка хімічної та фазової рівноваги, термодинаміка розчинів, електрохімія та хімічна кінетика. Натомість колоїдна хімія в багатьох університетах не виділяється окремо, а інтегрована з фізичною хімією, фізикою або фармацевтичним аналізом, а в Ново-Садському університеті (Сербія) взагалі $є$ елективним курсом.

Принципово відмінною рисою викладання дисциплін у ВНЗ Європи та України, в тому числі і ТДМУ, є значна частка лекцій у структурі кількості контактних аудиторних годин. Це загальновизнане підгрунтя впровадження методології проблемноорієнтованого навчання, яке сприяє формуванню здатності студентів до оперативної реакції, творчого евристичного мислення, уміння приймати відповідальні доцільні рішення, орієнтує на комплексне використання знань тощо. Студент опановує та/або закріплює теоретичні основи дисципліни впродовж лекційного курсу з наступним пошуком відповіді на проблемні питання дослідницького характеру, розв’язок яких вимагає опрацювання літератури не лише навчального, але й наукового характеру, у тому числі і фахових статей. Таке поєднання навчання, практики та наукової діяльності в єдине ціле сприяє формуванню студента як мотивованої особистості та $є$ ключовим елементом професіоналізації. За доцільне вважаємо перегляд розподілу аудиторних годин за аналізованими дисциплінами на користь лекційних занять.

Висновок. За консервативністю змісту навчальних програм з хімічних дисциплін медичних та фармацевтичних факультетів європейських уні- 
верситетів їх можна розташувати в ряді “Неорганічна хімія" > "Медична хімія" > “Органічна хімія” > “Фізична та колоїдна хімія”. Саме у медичних вузах, де кількості кредитів з хімічних дисциплін максимально наближені (Університет Дебрецена, Угорщина), студенти можуть максимально ефек-

\section{Список літератури}

1. Рашкевич Ю. М. Болонський процес та нова парадигма вищої освіти / Ю. М. Рашкевич. - Львів : Видавництво Львівської політехніки, 2014. - 168 с.

2. http://www.lu.lv/fileadmin/user_upload/lu_portal/ eng/international_students/Higher_professional_study_ program_MEDICINE_2013_2014_Autumn.pdf.

3. http://www.unipi.it/index.php/ects/ects-2013?ects_ id=CTF-LM5\#3388. тивно, 3 мінімально академічною різницею, включитися в навчальний процес. 3 погляду активного впровадження проблемно-орієнтованого навчання вважаємо доречним перерозподіл аудиторних годин за аналізованими хімічними дисциплінами на користь лекційних занять.

4. http://www.rsu.lv/eng/.

5. http://www.daad.ru/Publikationen/studying_in_ germany.pdf.

6. http://www.ud-mhsc.org/.

7. http://mu-sofia.bg/system/files/File/priem/ECTS_ CourseCat_IntStudents.pdf. 